\title{
THE FIRST OUTBREAK OF VIRAL ENCEPHALOPATHY AND RETINOPATHY IN FARMED SEA BASS (Dicentrarchus labrax) IN SLOVENIA
}

\author{
Rosvita Sitar ${ }^{1}$, Tanja Švara², Aleksandra Grilc Fajfar ${ }^{3}$, Sabina Šturm², Marko Cvetko², Irena Fonda4 ${ }^{4}$, Mitja Gombač2* $^{2 \star}$ \\ ${ }^{1}$ National veterinary institute, Veterinary Faculty, University of Ljubljana, Unit Nova Gorica, Pri hrastu 18, 5000 Nova Gorica, ${ }^{2}$ Institute of \\ pathology, wild animals, fish and bees, ${ }^{3}$ Institute of microbiology and parasitology, Veterinary Faculty, University of Ljubljana, Gerbičeva 60, \\ 1000 Ljubljana, ${ }^{4}$ Fonda.si d. o. o., Liminjanska cesta 117, 6320 Portorož, Slovenia
}

${ }^{*}$ Corresponding author, E-mail: mitja.gombac@vf.uni-lj.si

\begin{abstract}
Viral encephalopathy and retinopathy (VER) is considered a serious disease of several marine fish species, caused by RNA virus belonging to the family Nodaviridae, genus Betanodavirus. The disease is spread almost worldwide and causes significant losses among diseased fish. It is characterised by vacuolation of the central nervous system and the retina.

In July 2018, behavioural abnormalities i.e. altered swimming, swirling and vertical floating as well as lethargy and anorexia were observed in farmed sea bass (Dicentrarchus labrax) in the Gulf of Piran (Slovenia), associated with significant mortality. The disease initially occurred in juvenile sea bass, but later market-sized fish also became affected. Diseased fish displayed ocular opacity and multifocal skin ulceration on the head. Emaciation in some fish was also evident. Histopathology revealed characteristic vacuolation in the brain and retina. Performing a RT-PCR and RT-qPCR techniques, we have identified and confirmed the presence of betanodavirus nucleic acid in ocular and brain tissues. In addition, concentrations of the causative agent of VER in spleen and kidney did result in significantly higherviral yield than expected. Phylogenetic analysis showed that Slovenian isolate belongs to RGNNV species of betanodaviruses. Based on the clinical signs, gross and typical microscopic lesions and results of molecular analyses, we can conclude that farmed sea bass from the Gulf of Piran were affected with VER. To the best of our knowledge, this is the first report of VER in Slovenia.
\end{abstract}

Key words: viral encephalopathy and retinopathy; betanodavirus; sea bass; histopathology; RT-qPCR

\section{Introduction}

Viral encephalopathy and retinopathy (VER), also termed as viral nervous necrosis (VNN), is a serious neuropathological disease of more than 50 fish species almost worldwide (1). It occurs mostly in marine environment, but the outbreaks in freshwater fish have also been reported $(2,3$, 4). In marine aquaculture, VER is considered one of the most devastating infectious diseases (5), and sea bass (Dicentrarchus labrax) seems to be one of the most commonly and severely

Received: 4 September 2020

Accepted for publication: 7 July 2021 affected species (6). The disease affects mostly the larval and juvenile stages $(1,7)$, however, in several fish species, such as sea bass $(8,9)$ and grouper (Epinephelus septemfasciatus) (10), mass moralities have been also reported in adult and market-sized fish (1). Additionally, clinical signs and mortalities associated with VER were reported in wild fish species (11).

The causative agent is small (approximately $25 \mathrm{~nm}$ in diameter) spherical non-enveloped RNA virus, belonging to the genus Betanodavirus within family Nodaviridae $(1,12)$.

Based on the phylogenetic analysis of the RNA sequence of the T4 variable region, betanodaviruses have been clustered into four 
species, named striped jack nervous necrosis virus (SJNNV), red-spotted grouper nervous necrosis virus (RGNNV), barfin flounder nervous necrosis virus (BFNNV) and tiger puffer nervous necrosis virus (TPNNV) (13). It is reported that RGNNV exhibits the widest host range of warm water species $(14,15)$, including sea bass. Furthermore, two reassortants RGNNV/SJNNV and SJNNV/RGNNV have been described and reported to infect different fish species in Mediterranean $(5,16,17,18)$. Betanodaviruses have been often detected in apparently healthy wild marine fish $(19,20,21)$.

VER is characterized by typical changes in swimming pattern associated with affected nervous system (15), such as whirling, spiralling or looping, erratic swimming, lying down on the bottom, keeping vertical positions, lying on their sides or belly up and body curved $(8,9,10,22)$. In addition, lethargy, changes in skin pigmentation, skin erosion in the head region, ocular opacity and exophthalmia have been described $(8,11)$. Histopathological findings, most commonly characterized by vacuolation and necrosis of nerve cells of the brain, retina and spinal cord, are remarkably consistent among the various affected fish species $(15,23)$.

In this paper we describe the first occurrence of VER in Slovenia, including clinical signs, gross pathology, histopathological lesions and the results of molecular diagnostic procedures. Some epidemiological aspects are also discussed.

\section{Case presentation}

\section{Case history and clinical signs}

In July 2018, abnormal swimming behaviour associated with heavy mortalities occurred in sea bass reared in floating cages in the Gulf of Piran. Affected fish showed erratic swimming, impulsive movements, swirling, belly up or keeping vertical position with either head or caudal peduncle upside. Some were laying on their sides and body curved. Moreover, lethargy, anorexia, change in skin pigmentation, endo- or exophthalmia, ocular opacity and congestion of the head were observed. The disease initially occurred in older juveniles $(125 \mathrm{~g})$ and later market-sized fish became affected. There was no significant mortality observed in younger juveniles (50 g). Sea bream (Sparus aurata) also remained clinically unaffected (Table 1).

The marine fish farm concerned is the only one in Slovenia with the annual production of 100 tons and had no history of VER. No vaccination was carried out at that time; the juveniles introduced into the farm in 2017 had already been vaccinated against Listonella anguillarum, but not against other pathogens. In fact, the number of introduced juveniles was higher than in previous years, yet the density was only about $4.7 \mathrm{~kg} / \mathrm{m}^{3}$. Otherwise, husbandry practices and epizootiology in the area in the year of the outbreak generally did not differ from previous years.

In spring 2018, only sea bream juveniles were introduced into the farm, while the last introduction of sea bass juveniles took place in autumn 2017. At the time of the disease outbreak, the water temperature exceeded $26^{\circ} \mathrm{C}$.

The outbreak characterized by high losses lasted until the beginning of October 2018. The mortality firstly decreased in the population of juvenile sea bass $(125 \mathrm{~g})$ in the middle of September at the water temperature range $23-25^{\circ} \mathrm{C}$. About two weeks later at water temperature below $20^{\circ} \mathrm{C}$, the disease mitigated in adult sea bass as well (Figure 1). Nevertheless, after the mortality rate in autumn had decreased, abnormal swimming behaviour was still present in some fish and was regularly observed for months.

\section{Gross pathology}

Samples of clinically affected sea bass were collected from various cages of older juveniles

Table 1: Cumulative mortality, from July $1^{\text {st }}$ to December $31^{\text {st }}, 2018$, of different fish populations in the fish farm

\begin{tabular}{|c|c|c|c|c|c|c|}
\hline Fish species and category & $\begin{array}{c}\text { Adult } \\
\text { sea } \\
\text { bass }\end{array}$ & $\begin{array}{c}\text { Adult } \\
\text { sea } \\
\text { bass }\end{array}$ & $\begin{array}{c}\text { Juvenile } \\
\text { sea } \\
\text { bass }\end{array}$ & $\begin{array}{c}\text { Juvenile } \\
\text { sea } \\
\text { bass }\end{array}$ & $\begin{array}{c}\text { Juvenile } \\
\text { sea } \\
\text { bream }\end{array}$ & $\begin{array}{c}\text { Juvenile } \\
\text { sea } \\
\text { bream }\end{array}$ \\
\hline An average weight on July $1^{\text {st }}, 2018$ [g] & 870 & 300 & 125 & 50 & 110 & 20 \\
\hline $\begin{array}{l}\text { Cumulative mortality from July } 1^{\text {st }} \\
\text { to December } 31^{\text {st }}, 2018[\%]\end{array}$ & 51 & 48 & 45 & 8 & 2 & 4 \\
\hline
\end{tabular}




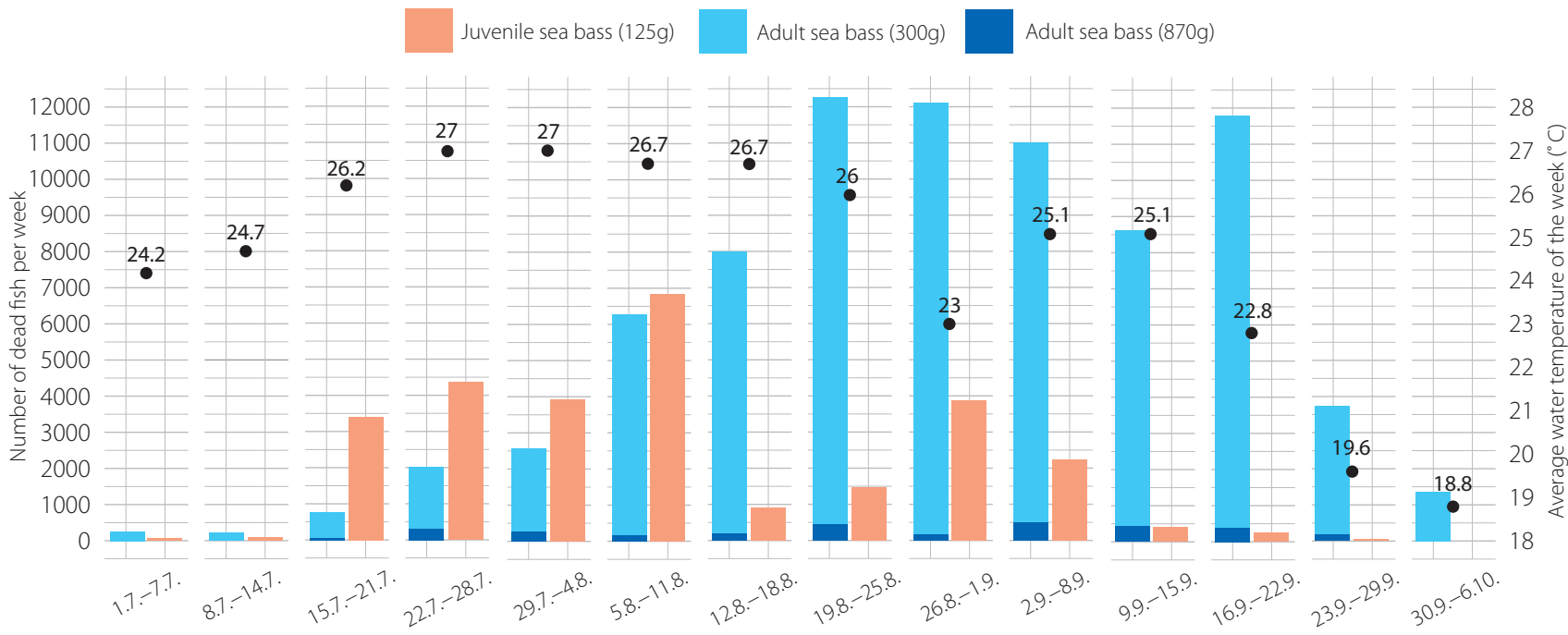

The perid of fourteen weeks from July to October 2018

Figure 1: Disease pattern regarding the number of dead fish per week in most affected populations (juvenile sea bass (125 g) and adult sea bass (300 g and $870 \mathrm{~g})$ ) of sea bass at different sea temperature (an average weekly temperature)

Figure 2: Viral encephalopathy and retinopathy. (a) Gross lesions included emaciation, ocular opacity and congestion of the head. In one fish, caudal fin erosion was noticed (arrowhead). (b) Close-up of the gross lesions showing ocular opacity and congestion on the head. (c) Characteristic vacuolation of the retina. HE. Scale bar: $100 \mu \mathrm{m}$; magnification: $100 \times$. (d) Characteristic vacuolation in the neuropil of the brain. HE. Scale bar: $100 \mu \mathrm{m}$; magnification: $200 \times$
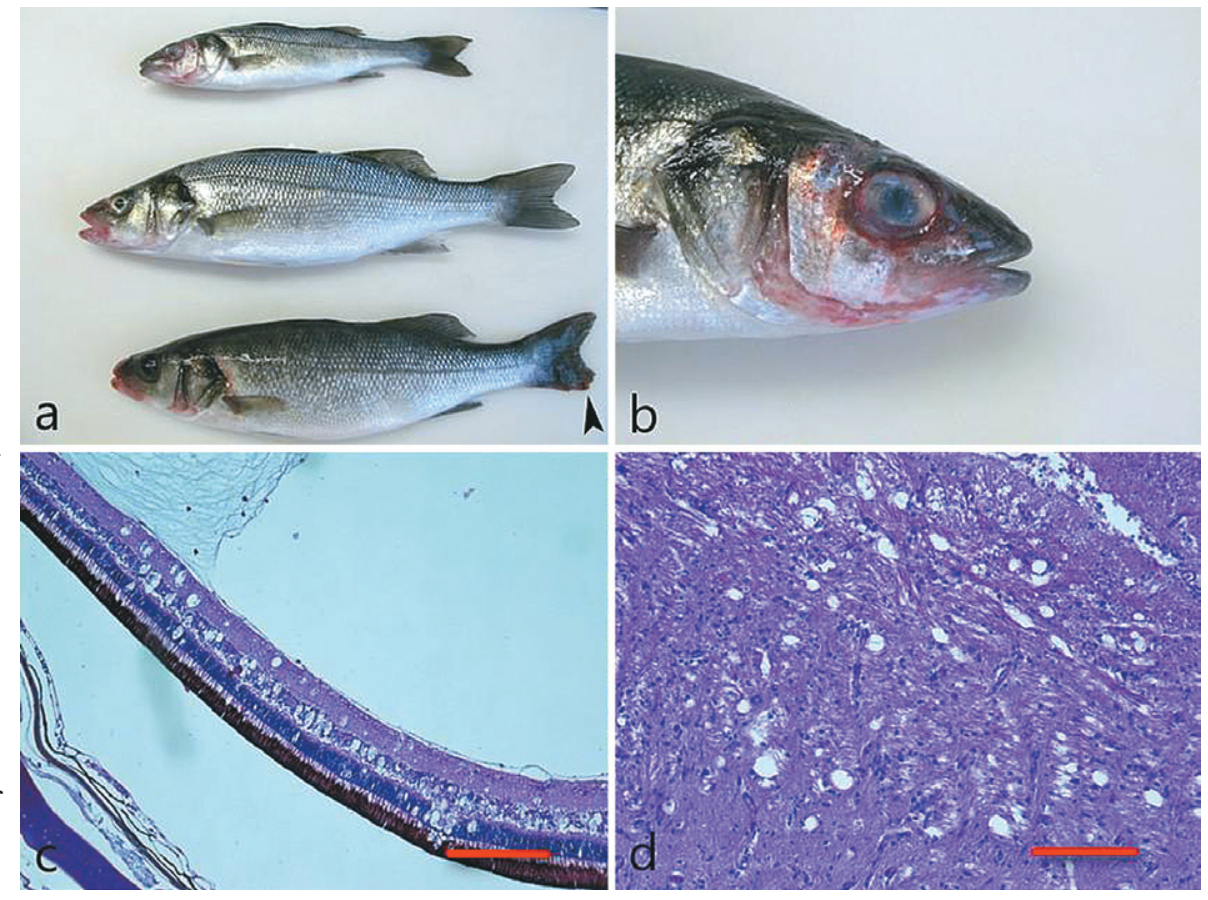

(125 g) and adults (300 g). Seven fish (four older juveniles, three adults) were subjected for necropsy. External examination revealed lesions limited to the head, which consisted of multifocal skin ulceration and congestion, ocular opacity, exophthalmia or endophthalmia (Figures 2a, b). Additionally, one fish was emaciated, and caudal fin erosion was evident in another one (Figures 2a). No lesions were observed with examination of internal organs.

\section{Histopathology}

Eye and brain samples were fixed in 10\% buffered formalin and routinely embedded in paraffin for histopathological examination. Four- $\mu \mathrm{m}$ thick tissue sections were first deparaffinised and then stained with haematoxylin and eosin (HE). Stained sections were examined with a light microscope. Microscopically, characteristic vacuolation in the retina and the brain was observed at different 
degrees (Figures 2c, d). Brain vacuolation was mostly present in the neuropil and only single vacuoles were found in the neurons. Only in one fish, multifocal mild perivascular lymphocytic infiltrates and gliosis were found in the brain stem.

\section{Virological analysis}

The brain tissue and eyes as well as spleen and kidney were pooled separately and submitted for laboratory viral diagnostics. Fish organ homogenates were screened for betanodavirus by RT-PCR and RT-qPCR following the methods documented by Nishizawa et al. (24) and the World Organisation for Animal Health (OIE) in Manual of Diagnostic Tests for Aquatic Animals (2016) (1). All tissue samples were stored at $-75^{\circ} \mathrm{C}$ for future analysis. Total RNA was extracted from supernatant of the organ homogenates (samples) using QIAamp Viral RNA (Qiagen, Germany). The extraction procedure was performed following the manufacturer's instructions. The RNA obtained was eluted in RNAse-free water. As a negative control, pool of negative fish tissue was processed alongside the virus isolate. Total RNA was added to a one-step RT-PCR for amplification of the certain genomic region within coat protein gene. A 427 nucleotide (nts) region targeting the $\mathrm{T} 4$ variable region of the RNA2 segment from diagnostic cases was amplified (Figure 3). RT-qPCR method was also introduced in the laboratory diagnostics of VER/VNN. A part of the RNA2 segment of viral genome was successfully detected using specific primers and MGB probe following OIE standard protocol (1).

Using molecular method RT-PCR we detected the presence of viral nucleic acid of betanodavirus successfully. With the RT-qPCR method, specific viral RNA in clinical samples can be detected quickly and specifically. Ct values obtained ranged from 15.88 (brain and bulbus) to 25.65 (spleen and kidney)

Confirmation of the positive results by both molecular methods, specific RT-PCR amplicon length for RNA2 genome region and the $\mathrm{Ct}$ values for RT-qPCR, corresponded $100 \%$.

The RNA2 segment of Slovenian betanodavirus isolate was sequenced and compared with known isolates from betanodavirus coat protein sequences from different countries and hosts. A partial sequence of coat protein of $286 \mathrm{nts}$ was aligned and used in phylogenetic analysis.

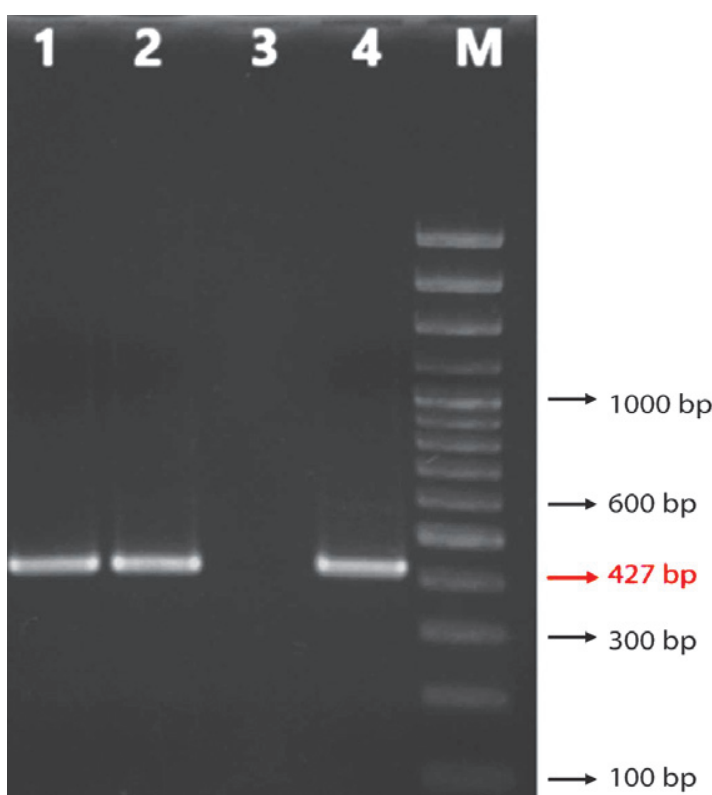

Figure 3: Agarose gel electrophoresis of RT-PCR positive samples of fish brain (1) and visceral organs (2) tested with F2/R3 primer pair. Reference negative (3) and positive (4) control. The red arrow indicates the expected size for the 427-bp amplicon. $\mathrm{M}=100$-bp size marker

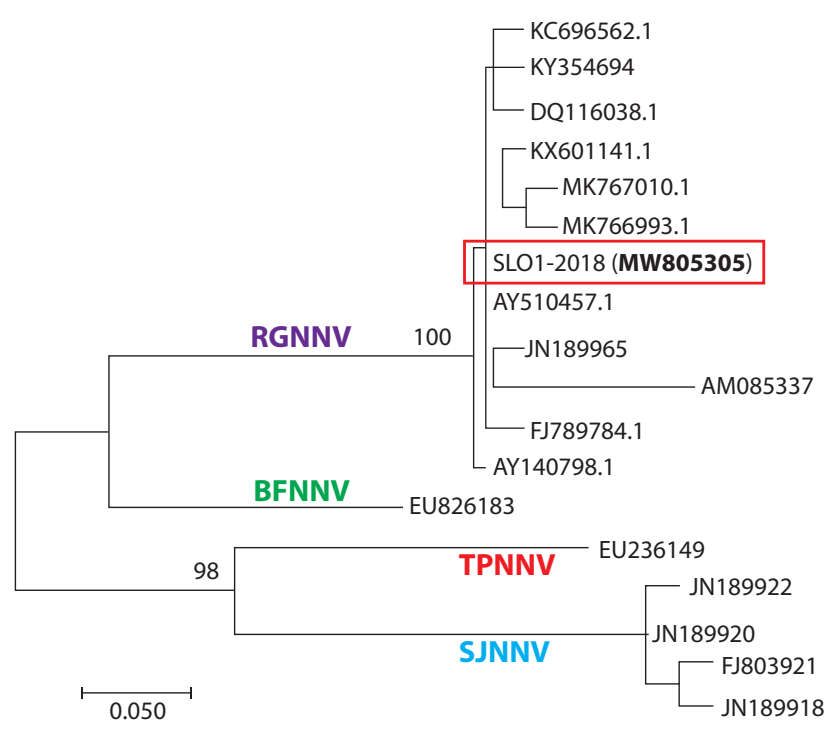

Figure 4: Maximum-likelihood (ML) phylogenetic tree based on partial RNA2 sequences depicting the phylogenetic relationships within genus Betanodavirus; subdivision of genus Betanodavirus is displayed by labeling the branches with different colors (violet: RGNNV; green: BFNNV; red: TPNNV; blue: SJNNV); ML bootstrap values $>60 \%$ are reported next to the nodes; scale is shown at the left as substitutions per site.

Phylogenetic analysis was generated with the program MEGA version 7.0. and employed the Maximum-likelihood method using the Kimura two-parameter model (25) (Figure 4). The significance of the branching order was assessed 
Table 2: Data related to the 18 betanodavirus isolates investigated in the phylogenetic analysis; abbreviations: unpubl., unpublished; n.d., data not available; t.s., this study

\begin{tabular}{|c|c|c|c|c|c|}
\hline Isolate & $\begin{array}{l}\text { Year of } \\
\text { isolation }\end{array}$ & $\begin{array}{l}\text { Country of } \\
\text { outbreak }\end{array}$ & Reference & $\begin{array}{l}\text { GenBank } \\
\text { accession no. }\end{array}$ & $\begin{array}{l}\text { Betanodavirus } \\
\text { species }\end{array}$ \\
\hline GMNNV-Korea & unknown & Korea & $\begin{array}{l}\text { Cha et al., } \\
\text { unpubl.(26) }\end{array}$ & DQ116038.1 & RGNNV \\
\hline 9Gr.A.2012 & 2012 & Greece & $\begin{array}{l}\text { Bitchava et al., } \\
2019(27)\end{array}$ & MK767010.1 & RGNNV \\
\hline SpPm-IAusc1586.10 & 2010 & Spain & $\begin{array}{l}\text { Olveira et al., } \\
2013(28)\end{array}$ & KC696562.1 & RGNNV \\
\hline G9508KS & 1995 & Taiwan & Chi et al., 2003(29) & AY140798.1 & RGNNV \\
\hline 28Gr.A.2013 & 2013 & Greece & $\begin{array}{l}\text { Bitchava et al., } \\
2019(27)\end{array}$ & MK766993.1 & RGNNV \\
\hline SFRG08/2013BSMu3 & 2013 & Korea & $\begin{array}{l}\text { Kim et al., } \\
\text { unpubl.(30) }\end{array}$ & KX601141.1 & RGNNV \\
\hline $570.16 .2008 c$ & 2008 & Italy & $\begin{array}{l}\text { Panzarin et al., } \\
2012(17)\end{array}$ & JN189965 & RGNNV \\
\hline “1” & 2009 & Tunisia & $\begin{array}{l}\text { Chérif et al., } \\
2010(31)\end{array}$ & FJ789784.1 & RGNNV \\
\hline $\begin{array}{l}\text { "Redspotted grouper nervous } \\
\text { necrosis virus" }\end{array}$ & unknown & China & $\begin{array}{l}\text { Lin et al., } \\
\text { unpubl.(32) }\end{array}$ & AY510457.1 & RGNNV \\
\hline Sa-I-97c & 1997 & Italy & $\begin{array}{l}\text { Toffolo et al., } \\
2007(33)\end{array}$ & AM085337 & RGNNV \\
\hline VNNV/S. aurata/I/425-10/Sep2008 & 2008 & Italy & $\begin{array}{l}\text { Toffan et al., } \\
2017(5)\end{array}$ & KY354694 & RGNNV \\
\hline SpSa-IAusc156.03c 2003 Larvae & 2003 & Spain & $\begin{array}{l}\text { Olveira et al., } \\
2009(16)\end{array}$ & FJ803921 & SJNNV \\
\hline $37.2 .2005 \mathrm{c}$ & 2005 & Portugal & $\begin{array}{l}\text { Panzarin et al., } \\
2012(17)\end{array}$ & JN189918 & SJNNV \\
\hline $250.1 .2009 c$ & 2009 & Cyprus & $\begin{array}{l}\text { Panzarin et al., } \\
2012(17)\end{array}$ & JN189920 & SJNNV \\
\hline $292.1 .2 .2009 c$ & 2009 & Greece & $\begin{array}{l}\text { Panzarin et al., } \\
2012(17)\end{array}$ & JN189922 & SJNNV \\
\hline BF93Hok & unknown & Japan & $\begin{array}{l}\text { Nerland et al., } \\
\text { unpubl.(34) }\end{array}$ & EU826138 & BFNNV \\
\hline TPKag93 & unknown & Japan & $\begin{array}{l}\text { Okinaka, } \\
\text { unpubl.(35) }\end{array}$ & EU236149 & TPNNV \\
\hline SLO1-2018 & 2018 & Slovenia & t.s. & MW805305 & RGNNV \\
\hline
\end{tabular}

by bootstrap resampling of 1000 replicates. Accession numbers of nucleotide sequences for VER/VNN worldwide isolates available at GenBank were cited and listed in Table 2.

Based on clinical signs, typical histopathological lesions followed by identification of the causative agent by molecular analysis, VER was diagnosed.

\section{Discussion}

Since late 80', mass mortalities in farmed sea bass showing abnormal swimming behaviour have been reported from Mediterranean region by several authors $(8,9,36)$. In summer 1995 , heavy losses associated with nodavirus infection occurred in juvenile and adult sea bass in several marine fish farms in Italy (9) and VER is currently considered to be endemic in Mediterranean basin (5). However, in Slovenia altered swimming behaviour associated with mass mortalities in marine aquaculture fish species had not been observed until recently. Clinical signs as well as gross and histopathological findings in our case were similar to those described by other authors $(8,9,22,37,38)$.

The temperature range at the time of the outbreak in July 2018 was in accordance with an optimal in-vitro growth temperature for betanodavirus species RGNNV at $25-30^{\circ} \mathrm{C}$ (39), and mortality significantly decreased at water temperature below $20^{\circ} \mathrm{C}$.

The source of infection in our case is difficult to define, considering that only sea bream was introduced into the farm in 2018. Transmission of the disease occurs mainly horizontally through contaminated water (1), but vertical transmission has also been demonstrated in several fish species (7). 
An additional possibility of transmission of the betanodavirus is represented from infected, asymptomatic specimens $(21,40)$. Results of infection trials reported by Castric et al. (41) showed that experimentally infected sea bream with no clinical signs of the disease was able to infect the juvenile sea bass by cohabitation. Furthermore, betanodavirus was detected in several marine invertebrate species, including Mediterranean mussel (Mytilus galloprovincialis) (42), which is the main cultured mollusc species in Slovenia. Moreover, the mollusc farming area Seča is in the immediate vicinity to the relevant fish farm. Kim et al. (43) confirmed infectivity of either BFNNVs or RGNNVs from shellfish, which may represent a potential risk for transmission of nodaviruses to cultured and wild host species. The ability of the sea bass nodavirus to survive at least one month at $25^{\circ} \mathrm{C}$ and at least one year at $15^{\circ} \mathrm{C}$ indicates that once released into the marine environment, it could remain widely spread during either cold or warm seasons (44). Thus, control measures possibly effective in hatcheries by implementation of proper disinfection procedures followed by introducing of betanodavirusfree broodstock, have limited results in preventing betanodavirus infections of farmed fish exposed to the marine environment in on-growing sites (15).

The nucleotide diversity of RGNNV isolates worldwide has been shown to vary depending on host species and environmental conditions $(18,45)$. Isolates from Italy, Spain, Portugal, Cyprus, Greece and Tunisia represent Mediterranean Basin.

Viral isolates collected from certain geographic area are generally similar to each other. In the present study, the most revealing spatial trend was the clear separation of isolates from the same geographical location. According to the genotype and geographical origin, SJNNV isolates within Mediterranean region and Japanese isolate from TPNNV species form two independent clusters.

Maximum-likelihood phylogenetic tree based on partial RNA2 sequences determined that the selected isolates within RGNNV species showed spatial correlation. In this study, geographic clustering of the virus isolates from Greece and Italy was observed. It is also important to note that within betanodavirus species RGNNV, closer phylogenetic relatedness of Korean RGNNV isolates with those from Greece and Italy was detected.

The determined partial T4 nucleotide sequence of Slovenian isolate showed 88.93 to $100 \%$ identity at the nucleotide level to the sequences among selected betanodavirus isolates analysed, highly related to strain RGNNV. The evolutionary analysis showed the phylogenetic relationships of newly characterized Slovenian isolate with the RGNNV species. Interestingly, it also exhibited 100\% identity to the virus isolate from China.

In this study, the determined partial RNA2 segment sequences representing four major betanodavirus species showed 65.04 to $100 \%$ identity at the nucleotide level to the selected sequences of 18 worldwide betanodavirus isolates.

In our case high viral load was detected also in spleen and kidney. Retina and central nervous system including the brain and spinal cord are key organs of the infection in which the virus actively replicates. Kidney and spleen are not considered the target organs and therefore not suitable for VER diagnosis, but nevertheless causative agent of the disease can be detected in many organs according to published data (1). Our results revealed that besides bulbus and brain tissue kidney and spleen could also be suitable tissues for analysis.

Considering the severity of the disease and based on available data suggesting the immunogenic characteristics of the NNV in sea bass, great effort has been made in vaccine development (46), including attenuated, inactivated, recombinant and DNA vaccines with promising results (47).

Recently, an inactivated injectable vaccine against VER caused by RGNNV species for sea bass has been authorised for use in the appointed Mediterranean countries: Spain, Italy, Croatia and Greece (Pharmaq) (48). It is to be administered to fish of a minimum weight of $12 \mathrm{~g}$, and the expected reduce of mortality caused by nodavirus (RGNNV species) in sea bass is up to 12 months post vaccination.

In these aspects, we believe that introduction of already vaccinated juveniles into Slovenian marine aquaculture facilities would be strongly recommended.

\section{Conclusion}

VER is one of the most devastating diseases of marine fish species with great impact on marine aquaculture. It is endemic in Mediterranean Basin, but the first outbreak in Slovenia occurred only in 2018. The disease caused increased mortality in juvenile and adult sea bass, which led to final loss of about $50 \%$ of affected populations. Phylogenetic analysis of Slovenian RGNNV isolate indicates its 
close relation to other isolates from Mediterranean Basin. Subsequently, an authorised vaccine for selected Mediterranean countries could reduce the mortality rate and economic losses caused by VER also in sea bass in Slovenia.

\section{References}

1. Viral encephalopathy and retinopathy. In: OIE manual of diagnostic tests for aquatic animals. $7^{\text {th }}$ ed. Paris : Office International des Epizooties, 2016: Chapter 2.3.12 https://www.oie.int/fileadmin/Home/eng/Health_standards/aahm/current/chapitre_viral_encephalopathy_retinopathy. pdf (June 2020)

2. Bigarré L, Cabon J, Baud M, et al. Outbreak of betanodavirus infection in tilapia, Oreochromis niloticus (L.), in fresh water. J Fish Dis 2009; 32: 667-73.

3. Bovo G, Gustinelli A, Quaglio F, et al. Viral encephalopathy and retinopathy outbreak in freshwater fish farmed in Italy. Dis Aquat Org 2011; 96: $45-54$.

4. Binesh CP. Mortality due to viral nervous necrosis in zebrafish Danio rerio and goldfish Carassius auratus. Dis Aquat Org 2013; 104: 257-60.

5. Toffan A, Pascoli F, Pretto T, et al. Viral nervous necrosis in gilthead sea bream (Sparus aurata) caused by reassortant betanodavirus RGNNV/SJNNV: an emerging threat for Mediterranean aquaculture. Sci Rep 2017; 7: e46755. doi: $10.1038 /$ srep46755

6. Toffan A. Viral encephalopathy and retinopathy. In: MedAID H2020 project blog. Mediterranean Aquaculture Integrated Development, 2018. http:// www.medaid-h 2020.eu/index.php/2018/09/06/ viral-encephalopathy-and-retinopathy/ (June 2020)

7. Munday BL, Kwang J, Moody N. Betanodavirus infections of teleost fish: a review. J Fish Dis 2002; 25: 127-42

8. Le Breton A, Grisez L, Sweetman J, Ollevier F. Viral nervous necrosis (VNN) associated with mass mortalities in cage-reared sea bass, Dicentrarchus labrax (L.). J Fish Dis 1997; 20: 145-51.

9. Bovo G, Nishizawa T, Maltese C, et al. Viral encephalopathy and retinopathy of farmed marine fish species in Italy. Virus Res 1999; 63: 143-6.

10. Fukuda Y, Nguyen HD, Furuhashi M, Nakai T. Mass mortality of cultured sevenband grouper, Epinephelus septemfasciatus, associated with viral nervous necrosis. Fish Pathol 1996; 31: 165-70.
11. Vendramin N, Patarnello P, Toffan, et al. Viral encephalopathy and retinopathy in groupers (Epinephelus spp.) in southern Italy: a threat for wild endangered species? BMC Vet Res 2013; 9: e20. doi: 10.1186/1746-6148-9-20

12. Mori KI, Nakai T, Muroga K, Arimoto M, Mushiake K, Furusawa I. Properties of a new virus belonging to nodaviridae found in larval striped jack (Pseudocaranx dentex) with nervous necrosis. Virology 1992; 187: 368-71.

13. Nishizawa T, Furuhashi M, Nagai T, Nakai T, Muroga K. Genomic classification of fish nodaviruses by molecular phylogenetic analysis of the coat protein gene. Appl Environ Microbiol 1997; 63: 1633-6.

14. Low CF, Syarul Nataqain B, Chee HY, Rozaini MZH, Najiah M. Betanodavirus: dissection of the viral cycle. J Fish Dis 2017; 40: 1489-96.

15. Doan QK, Vandeputte M, Chatain B, Morin $\mathrm{T}$, Allal F. Viral encephalopathy and retinopathy in aquaculture: a review. J Fish Dis 2017; 40: 717-42.

16. Olveira JG, Souto S, Dopazo CP, Thiéry R, Barja JL, Bandin I. Comparative analysis of both genomic segments of betanodaviruses isolated from epizootic outbreaks in farmed fish species provides evidence for genetic reassortment. J Gen Virol 2009; 90: 2940-51.

17. Panzarin V, Fusaro A, Monne I, et al. Molecular epidemiology and evolutionary dynamics of betanodavirus in southern Europe. Infect Genet Evol 2012; 12: 63-70.

18. Toffan A, Panzarin V, Toson M, Cecchettin $\mathrm{K}$, Pascoli F. Water temperature affects pathogenicity of different betanodavirus genotypes in experimentally challenged Dicentrarchus labrax. Dis Aquat Org 2016; 119: 231-8.

19. Barker DE, MacKinnon AM, Boston L, et al. First report of piscine nodavirus infecting wild winter flounder Pleuronectes americanus in Passamaquoddy Bay, New Brunswick, Canada. Dis Aquat Org 2002; 49: 99-105.

20. Gomez DK, Sato J, Mushiake K, Isshiki T, Okinaka Y, Nakai T. PCR-based detection of betanodaviruses from cultured and wild marine fish with no clinical signs. J Fish Dis 2004; 27: 603-8.

21. Giacopello C, Foti M, Bottari T, Fisichella V, Barbera G. Detection of viral encephalopathy and retinopathy virus (VERV) in wild marine fish species of the South Tyrrhenian Sea (Central Mediterranean). J Fish Dis 2013; 36: 819-21.

22. Grotmol S, Totland GK, Thorud K, Hjeltnes BK. Vacuolating encephalopathy and retinopathy 
associated with a nodavirus-like agent: a probable cause of mass moirtality of cultured larval and juvenile Atlantic halibut Hippoglossus hippoglossus. Dis Aquat Org 1997; 29: 85-97.

23. Munday BL, Nakai T. Special topic review: nodaviruses as pathogens in larval and juvenile marine finfish. World J Microbiol Biotechnol 1997; 13: 375-81.

24. Nishizawa T, Mori KI, Nakai T, Furusawa I, Muroga K. Polymerase chain reaction (PCR) amplification of RNA of striped jack nervous necrosis virus (SJNNV). Dis Aquat Org 1994; 18: 103-7.

25. Kimura M. A simple method for estimating evolutionary rate of base substitutions through comparative studies of nucleotide sequences. J Mol Evol 1980; 16: 111-20.

26. Cha SJ, Do JW, Park JW. Coat protein of a Korean isolate of fish nodavirus from grey mullet (Mugil cephalus). GenBank: DQ116038.1. Bethesda : National Center for Biotechnology Information, U.S. National Library of Medicine, 30. Jul. 2005. https://www.ncbi.nlm.nih.gov/nuccore/DQ116038.1 (Feb. 2019)

27. Bitchava K, Chassalevris T, Lampou E, Athanassopoulou F, Economou V, Dovas CI. Occurrence and molecular characterization of betanodaviruses in fish and invertebrates of the Greek territorial waters. J Fish Dis 2019; 42: 1773-83.

28. Olveira JG, Souto S, Dopazo CP, Bandin I. Isolation of betanodavirus from farmed turbot Psetta maxima showing no signs of viral encephalopathy and retinopathy. Aquaculture 2013; 406/407: 125-30.

29. Chi SC, Shieh JR, Lin SJ. Genetic and antigenic analysis of betanodaviruses isolated from aquatic organisms in Taiwan. Dis Aquat Org 2003; 55: 221-8.

30. Kim YC, Jeong HD. Highly frequent identification of betanodavirus BFNNV as well as RGNNV genotype in shellfish. GenBank: KX575831.1. Bethesda : National Center for Biotechnology Information, U.S. National Library of Medicine, 29. Oct. 2016. https://www.ncbi.nlm.nih.gov/nuccore/KX575831.1 (Feb. 2019)

31. Cherif N, Gagne N, Groman D, Kibenge F, Iwamoto T, Yason C, Hammami S. Complete sequencing of Tunisian redspotted grouper nervous necrosis virus betanodavirus capsid gene and RNA-dependent RNA polymerase gene. J Fish Dis 2010; 33: 231-40.

32. Lin L, Huang J, Weng S, He J. Partial capsid protein gene of red-spotted grouper nervous necro- sis virus in Guangdong province, P. R. China. GenBank AY510457.1. Bethesda : National Center for Biotechnology Information, U.S. National Library of Medicine, 26. Jul. 2016. https://www.ncbi.nlm. nih.gov/nuccore/AY510457.1 (Feb. 2019)

33. Toffolo V, Negrisolo E, Maltese C, et al. Phylogeny of betanodaviruses and molecular evolution of their RNA polymerase and coat proteins. Mol Phylogenet Evol 2007; 43: 298-308.

34. Nerland AH, Oevergaard A-C, Patel S, Nishizawa T. Complete sequence of RNA1 and RNA2 from the nodavirus strain BF93Hok isolated from barfin flounder, Verasper moseri at Hokkiado, Japan. GenBank: EU826138. Bethesda : National Center for Biotechnology Information, U.S. National Library of Medicine, 20. Jul. 2008. https:// www.ncbi.nlm.nih.gov/nuccore/EU826138 (Feb. 2019)

35. Okinaka Y. Comparison among the complete genomes of the four types of Betanodaviruses. GenBank: EU236149. Bethesda : National Center for Biotechnology Information, U.S. National Library of Medicine, 1. Nov. 2009. https://www. ncbi.nlm.nih.gov/nuccore/EU236149 (Feb. 2019)

36. Breul G, Bonami JR, Pepin JF, Pichot. Viral infection (picorna-like virus) associated with mass mortalities in hatchery-reared sea-bass (Dicentrarchus labrax) larvae and juveniles. Aquaculture 1991; 97: 109-16.

37. Lopez-Jimena B, Garcia-Rosado E, Thompson $\mathrm{KD}$, et al. Distribution of red-spotted grouper nervous necrosis virus (RGNNV) antigens in nervous and non-nervous organs of European seabass (Dicentrarchus labrax) during the course of an experimental challenge. J Vet Sci 2012; 13: 355-62.

38. Pascoli F, Serra M, Toson M, Pretto T, Toffan A. Betanodavirus ability to infect juvenile European sea bass, Dicentrarchus labrax, at different water salinity. J Fish Dis 2016; 39: 1061-8.

39. Iwamoto T, Nakai T, Mori K, Arimoto M, Furusava I. Cloning of the fish cell line SSN-1 for piscine nodaviruses. Dis Aquat Org 2000; 43: 81-9.

40. Terlizzi A, Tedesco P, Patarnello P. Spread of pathogens from marine cage aquaculture: a potential threat for wild fish assemblages under protection regimes? In: Carvalho ED, David GS, Silva RJ, eds. Health and environment in aquaculture. Rijeka : IntechOpen, 2012: 403-14. https:// www.intechopen.com/books/health-and-environment-in-aquaculture (Feb. 2019)

41. Castric J, Thiéry R, Jeffroy J, de Kinkelin P, Raymond JC. Sea bream Sparus aurata, an 
asymptomatic contagious fish host for nodavirus. Dis Aquat Org 2001; 47: 33-8.

42. Gomez DK, Baeck GW, Kim JH, Choresca $\mathrm{Jr} \mathrm{CH}$, Park SC. Molecular detection of betanodaviruses from apparently healthy wild marine invertebrates. J Invertebr Pathol 2008; 97: 197-202.

43. Kim YC, Kwon WJ, Kim MS, Kim KI, Min JG, Jeong HD. High prevalence of betanodavirus barfin flounder nervous necrosis virus as well as red-spotted grouper nervous necrosis virus genotype in shellfish. J Fish Dis 2018; 41: 233-46.

44. Frerichs GN, Tweedie A, Starkey WG, Richards $\mathrm{RH}$. Temperature, $\mathrm{pH}$ and electrolyte sensitivity, and heat, UV and disinfectant inactivation of sea bass (Dicentrarchus labrax) neuropathy nodavirus. Aquaculture 2000; 185: 13-24.

45. Vendramin N, Toffan A, Mancin M, et al. Comparative pathogenicity study of ten different betanodavirus strains in experimentally infected European sea bass, Dicentrarchus labrax (L.). J
Fish Dis 2014; 37: 371-83.

46. Miccoli A, Saraceni PR, Scapigliati G. Vaccines and immune protection of principal Mediterranean marine fish species. Fish Shellfish Immunol 2019; 94: 800-9.

47. Gonzales-Silvera D, Guardiola FA, Espinosa C, Chavez-Pozo E, Esteban MÁ, Cuesta A. Recombinant nodavirus vaccine produced in bacteria and administrated without purification elicits humoral immunity and protects European sea bass against infection. Fish Shellfish Immunol 2019; 88: 458-63.

48. Pharmaq. Pharmaq has received marketing authorizations (MA) for Nodavirus vaccine for European sea bass in Spain, Italy, Croatia and Greece. Oslo : Pharmaq, 2016. https://www. pharmaq.no/updates/pharmaq-has-rec/ (June, 2020)

\title{
PRVI IZBRUH VIRUSNE ENCEFALOPATIJE IN RETINOPATIJE PRI GOJENIH BRANCINIH (Dicentrarchus labrax) V SLOVENIJI
}

\author{
R. Sitar, T. Švara, A. Grilc Fajfar, S. Šturm, M. Cvetko, I. Fonda, M. Gombač
}

Izvleček: Virusna encefalopatija in retinopatija (VER) je nevarna bolezen številnih vrst morskih rib, ki jo povzroča nevrotropni RNA virus iz družine Nodaviridae, rod Betanodavirus. Bolezen je razširjena skoraj po vsem svetu in povzroča visok pogin okuženih rib. Zanjo so značilne vakuole v centralnem živčnem sistemu in retini. Konec julija 2018 so v ribogojnici v Piranskem zalivu pri brancinih opazili nepravilno plavanje, vrtenje in postavljanje v vertikalno smer ter letargijo in neješčnost, brancini so množično poginjali. Bolezen se je najprej pojavila pri mladicah, nato tudi pri konzumnih kategorijah brancinov. Obolele ribe so imele sivomotna očesna zrkla ter multifokalne kožne razjede na glavi, posamezne so bile shujšane. S histopatološko preiskavo smo ugotovili značilne vakuole v možganih in retini. Z molekularnima metodama RT-PCR in RT-qPCR smo potrdili prisotnost nukleinske kisline betanodavirusa v očesnem zrklu in možganih. Koncentracije virusa, ki so bile signifikantno višje od pričakovanih, smo ugotovili tudi v vranici in ledvicah. Na podlagi kliničnih znakov, makroskopskih in tipičnih histopatoloških sprememb ter rezultatov molekularnih preiskav lahko zaključimo, da so gojeni brancini v ribogojniciv Piranskem zalivu zboleliza VER. Opisani izbruh je prvi potrjeni primer te bolezniv Sloveniji.

Ključne besede: virusna encefalopatija in retinopatija; betanodavirus; brancin; histopatologija; RT-qPCR 